\title{
Movements of grey mullet Liza aurata and Chelon labrosus associated with coastal fish farms in the western Mediterranean Sea
}

\author{
P. Arechavala-Lopez ${ }^{1, *}$, I. Uglem ${ }^{2}$, P. Sanchez-Jerez ${ }^{1}$, D. Fernandez-Jover ${ }^{1}$, \\ J. T. Bayle-Sempere ${ }^{1}$, R. Nilsen ${ }^{3}$ \\ ${ }^{1}$ Dept. Marine Science and Applied Biology, University of Alicante, PO Box 99, 03080 Alicante, Spain \\ ${ }^{2}$ Norwegian Institute of Nature Research, Tungasletta 2, 7485 Trondheim, Norway \\ ${ }^{3}$ Institute of Marine Research, PO Box 6404, 9294 Tromsø, Norway
}

\begin{abstract}
Grey mullet occur in abundance around sea bream and sea bass farms where they forage on waste fish feed, a behaviour that could modify their natural movement pattern and distribution. In this study, we used visual census to record grey mullet aggregations at fish farms in the western Mediterranean Sea. We also mapped the movements of 2 species (Liza aurata and Chelon labrosus) between farms and adjacent coastal fishing areas, using acoustic telemetry. Grey mullet were frequently observed in the vicinity of the aquaculture cages and represented an important abundance and biomass at the farms. The presence and swimming depth of the tagged mugilids at any of the farms were neither significantly related to the time of the day nor the feeding period, except for $C$. labrosus, which showed a tendency towards deeper waters $(\sim 15 \mathrm{~m})$ during feeding periods. Some of the tagged fish stayed in the vicinity of the farms for longer periods and also moved frequently to other farms and nearby commercial fishing areas. Other tagged fish remained at the release location for shorter periods, before they moved out of the study area or possibly were caught by local fishermen. This is the first study using acoustic tagging in wild fish around Mediterranean fish farms that demonstrates that offshore aquaculture farms and local fishing grounds in the western Mediterranean Sea are connected through movements of wild fish. These farms attract and affect large numbers of commercially important fish species; probably causing ecological changes not only in the immediate proximity of farms but also several kilometres away from the farms.
\end{abstract}

KEY WORDS: Aggregation · Aquaculture $\cdot$ Behaviour $\cdot$ Connectivity $\cdot$ Fisheries $\cdot$ Telemetry $\cdot$ Wild fish

Resale or republication not permitted without written consent of the publisher

\section{INTRODUCTION}

A wide range of wild fish species are attracted to coastal aquaculture farms, where they shelter and/or feed on organic matter from cages (faeces and pellets) and organically enriched sediments (e.g. Carss 1990, Dempster et al. 2002, Tuya et al. 2006). The changed feeding habits of aggregated wild fish affect their biological and physiological condition in a way that, for example, their reproductive ability could be affected (Fernandez-Jover et al. 2007, Coz-Rakovac et al. 2008, Arechavala-Lopez et al. in press). Moreover, attracted marine fishes could move frequently and quickly among farms, visiting different facilities in the same area, as has been demonstrated for saithe Pollachius virens in Norwegian fjords (Uglem et al. 2009). This behavioural pattern could make wild fish potential - and hitherto not recognised - vectors for transmission of diseases and parasites among farms or to wild fish stocks.

It is believed that the biomass of wild fish in the areas around farms increases due to the fact that the high abundance of waste food increases growth rates (Dempster et al. 2002). Further, it is also possible that fish farms are connected to fishing areas through movements of wild fish. In the Mediterranean, artisanal fisheries exploit wild fish species aggregated at fish farms 
and may therefore benefit from this 'biomass export' at a local scale (Machias et al. 2006, Akyol \& Ertosluk 2010, Arechavala-Lopez et al. in press). Knowledge about the connectivity of fish farms and other marine areas through wild fish movements is crucial to understand how fish farming and wild fish stocks interact, which, in turn, is essential for managing aquaculture and fisheries in coastal zones.

Grey mullet (Osteichthyes, family Mugilidae) are commonly found in the coastal regions and support artisanal and recreational fisheries in the Mediterranean Sea (McDowall 1988, Blaber 1997, Coll et al. 2004). Grey mullet are also frequently found around sea bream and sea bass farms (Dempster et al. 2002, Fernandez-Jover et al. 2008), where they play an important ecological role, consuming considerable amounts of waste feed from the farms and thus also diminishing the environmental impact of the fish farming activity (Porter et al. 1996, Katz et al. 2002, Lupatsch et al. 2003, Fernandez-Jover et al. 2008). In the present study, we determined the abundance and movement patterns of grey mullet around European sea bass and gilthead sea bream farms on a typical farm area in southeast Spain. Visual census beneath sea cages was used to assess abundances, and individual mullet equipped with acoustic transmitters were tracked in an array of automatic receivers positioned at and around several fish farms. Specifically, we sought to (1) document grey mullet aggregations in close proximity to sea cages, (2) study the movement of mugilids among fish farms and to adjacent coastal fishing areas and (3) assess the presence at and pattern of association to the farms in relation to time of day and feeding time for 2 mugilid species, Liza aurata (Risso, 1810) and Chelon labrosus (Risso, 1827).

\section{MATERIALS AND METHODS}

Study area. The study was carried out from 13 October 2008 to 15 March 2009 in Guardamar Bay (UTM: 30S 0710736 4219249), Alicante, southeast Spain (Fig. 1). In this bay, 6 fish farm facilities, belonging to 3 different aquaculture companies, grow European sea bass Dicentrarchus labrax, gilthead sea bream Sparus aurata and meagre Argyrosomus regius. The farms are located 3 to $4 \mathrm{~km}$ from the shore and the distances between farms vary from 1 to $5 \mathrm{~km}$. The farms are located on soft muddy bottoms at depths ranging from 23 to $30 \mathrm{~m}$. The area supports small-scale traditional and recreational fisheries (Forcada et al. 2009).

Estimation of abundances of grey mullet around farms. The abundance and the approximate size distributions of grey mullet around farms in the Guardamar Bay were estimated by conducting rapid visual counts (RVCs; Kingsford \& Battershill 1998) to reduce count bias (Ribeiro et al. 2005), following the method out-

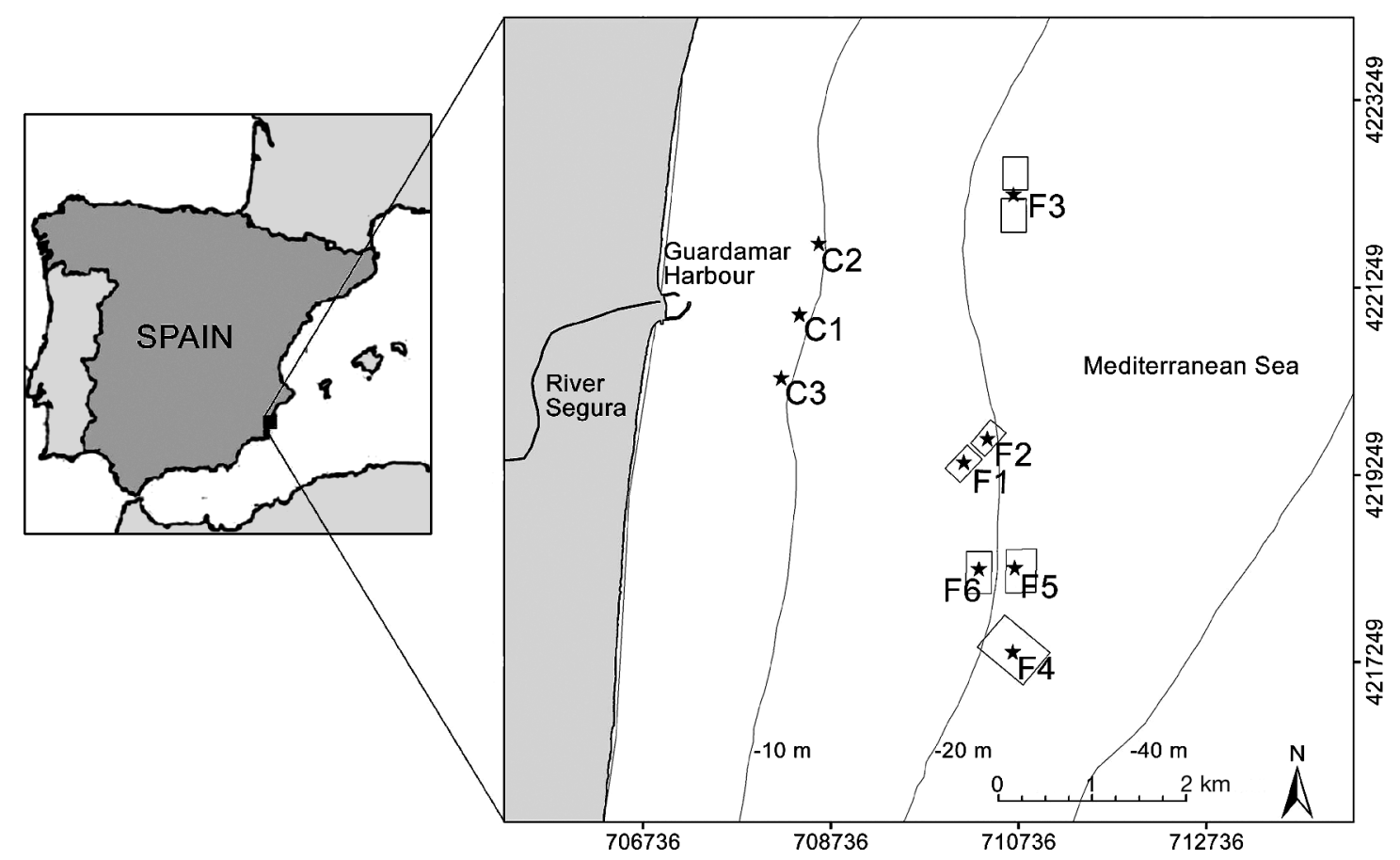

Fig. 1. Study area in Guardamar Bay, south-eastern Spain with locations of the farm facilities (rectangles) and the receivers (stars) used to track grey mullet equipped with acoustic transmitters. Coordinates are from UTM grid zone $30 \mathrm{~S}$. $\mathrm{F}_{\mathrm{n}}$ indicates the position of receivers at farms; $\mathrm{C}_{\mathrm{n}}$ indicates the position of receivers at coastal fishing areas; all receivers have a detection radius of $\sim 350 \mathrm{~m}$. 
lined by Dempster et al. (2002). Fish were counted at 5 different times from October 2008 to March 2009, at 6 randomly selected sites in immediate proximity to the farms F1 and F2 (Fig. 1). Each count covered a volume of approximately $11250 \mathrm{~m}^{3}(15 \mathrm{~m}$ wide $\times 15 \mathrm{~m}$ deep $\times$ $50 \mathrm{~m}$ long) (Dempster et al. 2002) and was conducted simultaneously by 2 divers. The first diver estimated the abundance of the dominant species present. Fish were counted in groups of $1,2-5,6-10,11-30,31-50$, 51-100, 101-200, 201-500 and 500+ to minimise error, based on the method of Harmelin-Vivien et al. (1985). The average total length (TL) of each group was also recorded. The second diver followed slightly behind the first and specifically looked for both highly mobile species and smaller, less obvious fish that may have been missed by the first diver. As grey mullet commonly occur in mixed species shoals, it was difficult to distinguish different mullet species during the visual counts. Chelon labrosus, Liza aurata, L. Saliens, L. ramada and Mugil cephalus were therefore pooled as Mugilidae. At least 1 individual of each of these species was observed during the counts. Biomass conversions from visual census abundance were made on the basis of published length-weight relationship of wild fish (Verdiell-Cubedo et al. 2006), and all raw data were arranged using ecoCEN software (Bayle-Sempere et al. 2001).

Tagging and tracking of grey mullet. Movement patterns of mugilids at farms were studied by tagging 14 golden grey mullet Liza aurata and 8 thicklip grey mullet Chelon labrosus with acoustic transmitters and by monitoring their spatiotemporal distribution using an array of automatic receivers positioned at different farms and adjacent coastal fishing areas in Guardamar Bay (Fig. 1). The mugilids were captured in immediate proximity to farm F1 (distance from farm $<50 \mathrm{~m}$, see Fig. 1) by a baited fish trap (L. aurata) or gill nets $(C$. labrosus). Only fish showing no signs of damage after capture were tagged. L. aurata were tagged on 15 October 2008 and released on 17 October 2008 after being kept in a sea cage for 2 d. C. labrosus were tagged and released on 4 February 2009. Both species were released close $(<10 \mathrm{~m})$ to the cages of farm F1. The size of the tagged fish corresponded to the size of mugilids that aggregated at the farms in the study area.

Before tagging, the fish were anaesthetized by immersion in an aqueous solution of MS222 (0.1 to $0.12 \mathrm{~g}$ MS222 $\mathrm{l}^{-1}$, anaesthetic volume $40 \mathrm{l}$, immersion period $3 \pm 1 \mathrm{~min}$, temperature in solution: 15 to $17^{\circ} \mathrm{C}$ ). Once anaesthetized, the fish were placed ventral side up onto a V-shaped surgical table. An incision $(\sim 1 \mathrm{~cm})$ was made on the ventral surface posterior to the pelvic girdle using a scalpel. The transmitter (Vemco, model V9P-6L-69KHz-S256, $9 \times 39 \mathrm{~mm}$, weight in air/water = $4.6 / 2.2 \mathrm{~g}$, depth range $=200 \mathrm{~m}$ ) was inserted through the incision and pushed into the body cavity above the pelvic girdle. The transmitters were equipped with a pressure sensor. The incision was closed with 2 or 3 independent silk sutures (3/0 Ethicon). The fish were regularly sprayed with water during the surgery (mean $\pm \mathrm{SD}$ handling time $=3 \pm 1 \mathrm{~min}$, mean recovery time $=$ $2 \pm 1 \mathrm{~min})$. Before each incision, the surgical equipment was rinsed in $70 \%$ ethanol and allowed to dry. In addition, both species were tagged with external streamer tags near the dorsal fin base (Hallprint) to enable individual identification in case of recapture. Tagged Liza aurata were allowed to recover for $2 \mathrm{~d}$ in a storage pen before being released by slowly lowering one side of the net wall. After tagging, the Chelon labrosus were allowed to recover for 3 to $7 \mathrm{~min}$ in a large container (2250 1) on board the fishing vessel. They were released after they showed normal swimming behaviour. All handling and tagging was conducted according to the Spanish regulations for the treatment and welfare of animals (Real Decreto 1201/2005, published in BOE no. 252, 21 October 2005).

The movements and distribution of the tagged grey mullet were recorded by 9 receivers (Vemco, model VR2) positioned to monitor fish farms and coastal fishing areas (Fig. 1). The receivers at the 6 study farms and at the 3 coastal sites were attached on anchored ropes at a water depth of 10 to $12 \mathrm{~m}$. Range tests indicated that the average receiver detection range varied between 300 and $400 \mathrm{~m}$. The transmitters emitted unique coded signals such that each fish could be individually recognized. When a tagged fish was present within a receiver range, the transmitter identification code, date, time and depth of detection were recorded. All receivers were deployed for 23 wk following 13 October 2008.

Data analyses. The receivers occasionally recorded acoustic noise that was interpreted as a single reception of a transmitter ID code. To exclude such false signals, single detections within a $30 \mathrm{~min}$ period were considered erroneous. Presence within the detection range of a receiver was thus defined as when a fish was detected twice or more within a $30 \mathrm{~min}$ period. Likewise, a fish was considered as having left a receiver site if the period between detections was more than $30 \mathrm{~min}$. The $30 \mathrm{~min}$ interval was determined on the basis of observations of detection intervals during the recovery period for the 14 Liza aurata, i.e. the maximum number of fish that could be expected to be in the detection range of a receiver simultaneously. During this period, the observed average individual detection intervals were approximately 12 to $15 \mathrm{~min}$.

Mortality was determined by analysing variations in swimming depth. When swimming depths corresponded to the depth at the specific receiver location and remained the same until the end of the study pe- 
Table 1. Frequency (proportion of transects in which the listed groups were recorded), mean $( \pm \mathrm{SE})$ abundance and biomass of fish from visual counts

\begin{tabular}{|lccc|}
\hline Taxon & $\begin{array}{c}\text { Frequency } \\
(\%)\end{array}$ & $\begin{array}{c}\text { Abundance } \\
\left.\text { (ind. } 1000 \mathrm{~m}^{-3}\right)\end{array}$ & $\begin{array}{c}\text { Biomass } \\
\left(\mathrm{kg} 1000 \mathrm{~m}^{-3}\right)\end{array}$ \\
\hline Boops boops & 57 & $6.3 \pm 1.7$ & $347.1 \pm 119.4$ \\
Caranx rhonchus & 40 & $2.1 \pm 1.0$ & $380.6 \pm 178.1$ \\
Engraulis encrasicolus & 10 & $6.5 \pm 4.1$ & $55.6 \pm 34.2$ \\
Myliobatis aquila & 7 & $0.1 \pm 0.1$ & $24.5 \pm 17.1$ \\
Mugilidae & 63 & $15.5 \pm 5.2$ & $14537.5 \pm 7206.7$ \\
Oblada melanura & 13 & $1.2 \pm 0.7$ & $9.8 \pm 7.2$ \\
Pomatomus saltatrix & 13 & $0.1 \pm 0.1$ & $38.7 \pm 23.7$ \\
Sardinella aurita & 27 & $17.6 \pm 7.4$ & $240.9 \pm 120.8$ \\
Sarpa salpa & 3 & $0.2 \pm 0.1$ & $32.6 \pm 32.6$ \\
Sphyraena sphyraena & 3 & $0.1 \pm 0.1$ & $2.9 \pm 2.9$ \\
Trachurus mediterraneus & 47 & $8.1 \pm 2.7$ & $282.3 \pm 92.6$ \\
Trachinotus ovatus & 33 & $22.4 \pm 9.1$ & $21381.8 \pm 10945.5$ \\
\hline
\end{tabular}

farms, each day was divided into a feeding period (09:00 to 14:59 h) and a non-feeding period (00:00 to 08:59 and 15:00 to 23:59 h). Levene's tests were used to analyse heterogeneity of variances. Generalized linear model (GLM) repeated measurements analyses were used to test for differences in presence and daily detections (dependent variable) between species (fixed factor) and individuals (random factor) among time of the day ( $24 \mathrm{~h}$, covariate); and for differences in swimming depth (dependent variable) between species (fixed factor) and individuals (random factor) among 2 different periods of a day (day vs. night periods, and feeding vs. non-feeding periods; covariates). The GLM repeated mea-

riod, the fish was defined as being dead. Movements among receivers were defined as 1-way movements, i.e. if a fish moved from one receiver area to another and then returned, this was recorded as 2 separate movements. As the recovery method varied between the 2 species, data from the first $48 \mathrm{~h}$ after release was not used for statistical analyses, to avoid possible tagging effects aimed at comparing the 2 species. Variation in diurnal presence of grey mullet at fish farms was examined by comparing the total daily numbers of detections with the number of detections within $24 \times$ $1 \mathrm{~h}$ intervals at any of the 6 farms in the bay for each fish (12 individuals of Liza aurata and 6 individuals of Chelon labrosus). Only days where a fish had been detected more than twice at a farm were included in the analyses of diurnal presence. Variation in vertical distribution of grey mullet at farms in relation to time of day and farm feeding schedule was examined by comparing the mean swimming depths of each fish $(12$ individuals of L. aurata and 6 individuals of C. labrosus) at any of the 6 farms among different times of the day (same data set as was used to examine variation in diurnal presence). To analyse diurnal variation in swimming depth, each day was divided into $2 \times 12 \mathrm{~h}$ periods with the period from 08:00 to 19:59 $\mathrm{h}$ being defined as day (from dawn to dusk) and the remaining period as night (from dusk to dawn). Furthermore, to analyse swimming depth in relation to feeding at sures procedure provides analysis of variance when the same measurement (detections) is made several times on each subject or case (individuals). All data were analysed using commercially available statistical software (SPSS 15.0).

\section{RESULTS}

Altogether, 12 groups of fishes were observed in the vicinity of the study farms in Guardamar Bay during the visual census (Table 1). Grey mullet (Mugilidae) were the most frequently observed fish in the visual counts (found in $63 \%$ of the counts) at the farms, followed by bogue Boops boops (57\%) and horse mackerel Trachurus mediterraneus (47\%) (Table 1). Derbio Trachinotus ovatus and round sardinella Sardinella aurita were the most abundant fish species occurring at farms in terms of number of fish $(22.4 \pm 9.1$ and 17.6 \pm 7.4 ind. $1000 \mathrm{~m}^{-3}$, respectively), while grey mullet were the third most abundant group of fish at farms $\left(15.5 \pm 5.2\right.$ ind $1000 \mathrm{~m}^{-3}, 19.4 \%$ of the total number of fish, Table 1). Furthermore, grey mullet represented $38.9 \%$ of the total biomass present at the fish farms (14537.5 $\pm 7206.7 \mathrm{~kg} 1000 \mathrm{~m}^{-3}$; Table 1$)$, being the second most abundant fish with respect to biomass, after derbio T. ovatus $\left(21381.8 \pm 10945.5 \mathrm{~kg} 1000 \mathrm{~m}^{-3}\right)$. The estimated size distributions of grey mullet captured at

Table 2. Length and weight of observed (visual counts) and tagged/released grey mullet at the fish farms in Guardamar Bay. $\mathrm{N}=$ number of species, N/A = not applicable

\begin{tabular}{|c|c|c|c|c|c|c|c|c|c|}
\hline \multirow[t]{2}{*}{ Taxon } & \multirow[t]{2}{*}{$\mathrm{N}$} & \multirow[t]{2}{*}{ Capture type } & \multicolumn{3}{|c|}{ Length $(\mathrm{cm})-$} & \multicolumn{3}{|c|}{- Weight $(\mathrm{kg})-$} & \multirow{2}{*}{$\begin{array}{l}\text { Release date } \\
\text { (d/mo/yr) }\end{array}$} \\
\hline & & & Mean $\pm \mathrm{SD}$ & Max. & Min. & Mean \pm SD & Max. & Min. & \\
\hline Liza aurata & 14 & Baited trap & $47.9 \pm 7.2$ & 64 & 40 & $1.9 \pm 1.0$ & 3.1 & 0.7 & $17 / 10 / 08$ \\
\hline Chelon labrosus & 8 & Gill net & $60.1 \pm 4.8$ & 70 & 54 & $2.4 \pm 0.5$ & 3.9 & 1.8 & 04/02/09 \\
\hline Mugilidae & 4956 & Visual census & $47.7 \pm 10.8$ & 68 & 30 & $2.0 \pm 1.5$ & 3.9 & 0.3 & N/A \\
\hline
\end{tabular}



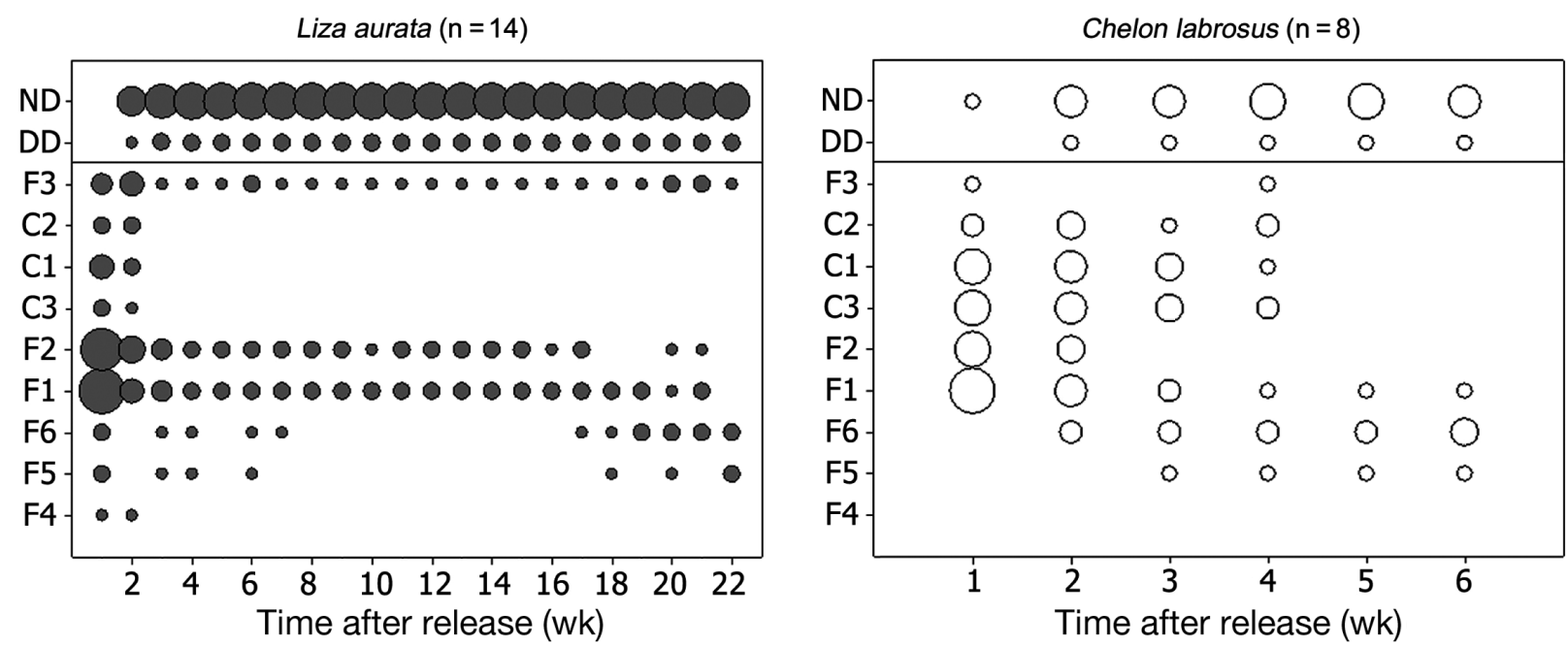

Fig. 2. Proportions of tagged Liza aurata ( $\bullet$ ) and Chelon labrosus (0), given by bubble size, recorded by the different receivers, organised from north to south. The smallest bubble represents 1 fish, i.e. $7.14 \%$ for L. aurata and $12.5 \%$ for C. labrosus, while the largest represents $100 \%$ or 14 fish for L. aurata and 8 fish for C. labrosus. ND: no data recorded; DD: fish defined as being dead. Position of receivers at fish farms: F1 (release farm for tagged fish), F2, F3, F4, F5, F6; and coastal zones: C1, C2, C3

fish farms indicated that the size of the tagged mullet were representative of the mugilids aggregated in immediate proximity to the farms (Table 2).

The tagged Liza aurata were detected by all receivers (Fig. 2). During the first 2 wk after release, a relatively high proportion of the L. aurata moved from the release farm to other farms and to the area covered by the receivers positioned between the farms and the shoreline (i.e. the coastal fishing area). Two of the 14 tagged $L$. aurata died during the first 2 wk after release. Nine $L$. aurata $(64.3 \%)$ were not observed after Week 4, possibly because they had left the study area, had been fished or were outside the detection ranges of the receivers (Fig. 2). Three L. aurata $(21.4 \%)$ remained around the fish farms for the entire 22 wk study period (Fig. 2). During this period, these fish made a high number of movements among farms, without visiting the coastal area where the acoustic recorders were located (Table 3). Altogether, 11 (78.6\%) L. aurata were detected at farms other than the farm where the tagged fish were released during the study period (Table 3).

Three out of 8 tagged Chelon labrosus $(37.5 \%)$ were observed at farms other than the farm where the tagged fish were released during the 6 wk study period (Fig. 2). During the first 4 wk these fish made repeated movements among the release farm, the southern farms and the area covered by the receivers positioned between the farms and the shoreline (Fig. 2, Table 3). Four C. labrosus (50\%) were observed in the areas around the release farm the first

Table 3. Recorded time and number of movements (mov.) of the 18 tagged grey mullet (12 individuals of Liza aurata and 6 individuals of Chelon labrosus) that moved from the release farm to other fish farms (F) or coastal fishing areas (C) during the study period. Num. F: number of farms where the fish were detected. Fish defined as being dead were not included

\begin{tabular}{|lccccccc|}
\hline Code & $\begin{array}{c}\text { Recorded } \\
\text { time (day) }\end{array}$ & $\begin{array}{c}\text { Total } \\
\text { mov. }\end{array}$ & $\begin{array}{c}\mathrm{F}-\mathrm{F} \\
\text { mov. }(\%)\end{array}$ & $\begin{array}{c}\mathrm{F}-\mathrm{C} \\
\text { mov. }(\%)\end{array}$ & $\begin{array}{c}\mathrm{F}-\mathrm{F} \\
\text { mov. }\left(\mathrm{d}^{-1}\right)\end{array}$ & $\begin{array}{c}\mathrm{F}-\mathrm{C} \\
\text { mov. }\left(\mathrm{d}^{-1}\right)\end{array}$ & $\begin{array}{c}\text { Num. } \\
\text { L. aurata }\end{array}$ \\
L1 & 2 & 2 & 0 & 100 & 0 & 1 & 1 \\
L2 & 21 & 7 & 100 & 0 & 0.33 & 0 & 3 \\
L3 & 2 & 2 & 50 & 50 & 0.5 & 0.5 & 0 \\
L4 & 146 & 101 & 100 & 0 & 0.69 & 0 & 5 \\
L5 & 9 & 42 & 85.7 & 14.3 & 4 & 0.66 & 5 \\
L7 & 5 & 7 & 71.4 & 28.6 & 1 & 0.4 & 3 \\
L9 & 140 & 5 & 100 & 0 & 0.03 & 0 & 3 \\
L10 & 5 & 6 & 100 & 0 & 1.2 & 0 & 2 \\
L11 & 7 & 22 & 100 & 0 & 3.14 & 0 & 4 \\
L12 & 2 & 2 & 50 & 50 & 0.5 & 0.5 & 1 \\
L13 & 4 & 3 & 66.7 & 33.3 & 0.5 & 0.25 & 2 \\
L14 & 150 & 152 & 100 & 0 & 1.01 & 0 & 4 \\
Average & 41.1 & 29.3 & 77 & 23 & 1.08 & 0.28 & 2.8 \\
C. labrosus & & & & & & & \\
Ch2 & 20 & 30 & 63.3 & 36.7 & 0.95 & 0.55 & 2 \\
Ch3 & 3 & 1 & 100 & 0 & 0.33 & 0 & 1 \\
Ch4 & 2 & 2 & 50 & 50 & 0.5 & 0.5 & 0 \\
Ch5 & 6 & 7 & 57.1 & 42.9 & 0.66 & 0.5 & 1 \\
Ch6 & 30 & 38 & 47.4 & 52.6 & 0.6 & 0.66 & 5 \\
Ch7 & 23 & 37 & 73 & 27 & 1.17 & 0.43 & 4 \\
Average & 14 & 19.2 & 65.1 & 34.9 & 0.70 & 0.44 & 2.2 \\
\hline
\end{tabular}


week after release, but never again thereafter in the whole study area (Fig. 2, Table 3). One C. labrosus died a few days after tagging (Fig. 2).

The number of movements among farms of the Liza aurata and the Chelon labrosus that were detected at farms other than the release farm, ranged from 1 to 152 and 1 to 38 movements, respectively (Table 3). A high proportion of the total movements of L. aurata occurred among farms $(77 \%)$ and the rest between farms and coastal areas $(23 \%)$. The proportion of the total movements among farms of C. labrosus (65.1\%) was lower than $L$. aurata, while the movements from farms to coastal areas were higher $(34.9 \%$; Table 3$)$. For $L$. aurata, the average numbers of movements among farms and from farms to the coastal area in relation to time (number of days from release to last detection) were 1.08 and 0.28 movements $\mathrm{d}^{-1}$, respectively (Table 3). For C. labrosus the average numbers of movements among farms and from farms to the coastal area in relation to time within the study area were 0.70 and 0.44 movements $\mathrm{d}^{-1}$, respectively (Table 3 ). On average, the $L$. aurata that were detected at farms other than the release farm, were observed at 2.8 farms, while the $C$. labrosus that moved among farms were observed at 2.2 farms (Table 3 ).

The presence of tagged mugilids at any of the farms was not significantly related to the time of the day (Fig. $3 ; F=0.9$, df $=23, \mathrm{p}=0.6$ ) and significant differences were not observed among different individuals throughout the $24 \mathrm{~h}$ of a day, regardless of the species or period $(F=3.4, \mathrm{df}=17, \mathrm{p}=0.09)$. The daily detection rate of Liza aurata appeared to be higher than for Che-

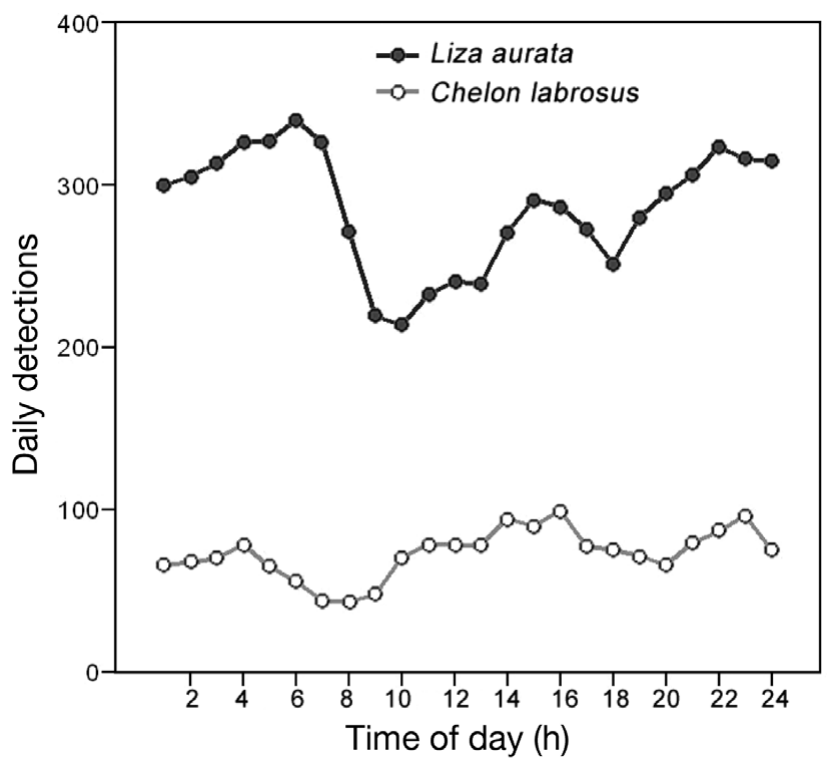

Fig. 3. Estimated marginal means of daily detections (GLM results) of both tagged species, Liza aurata $(\bullet ; \mathrm{n}=12)$ and Chelon labrosus $(0 ; \mathrm{n}=6)$, in the vicinity of fish farms throughout the day $(\mathrm{h})$

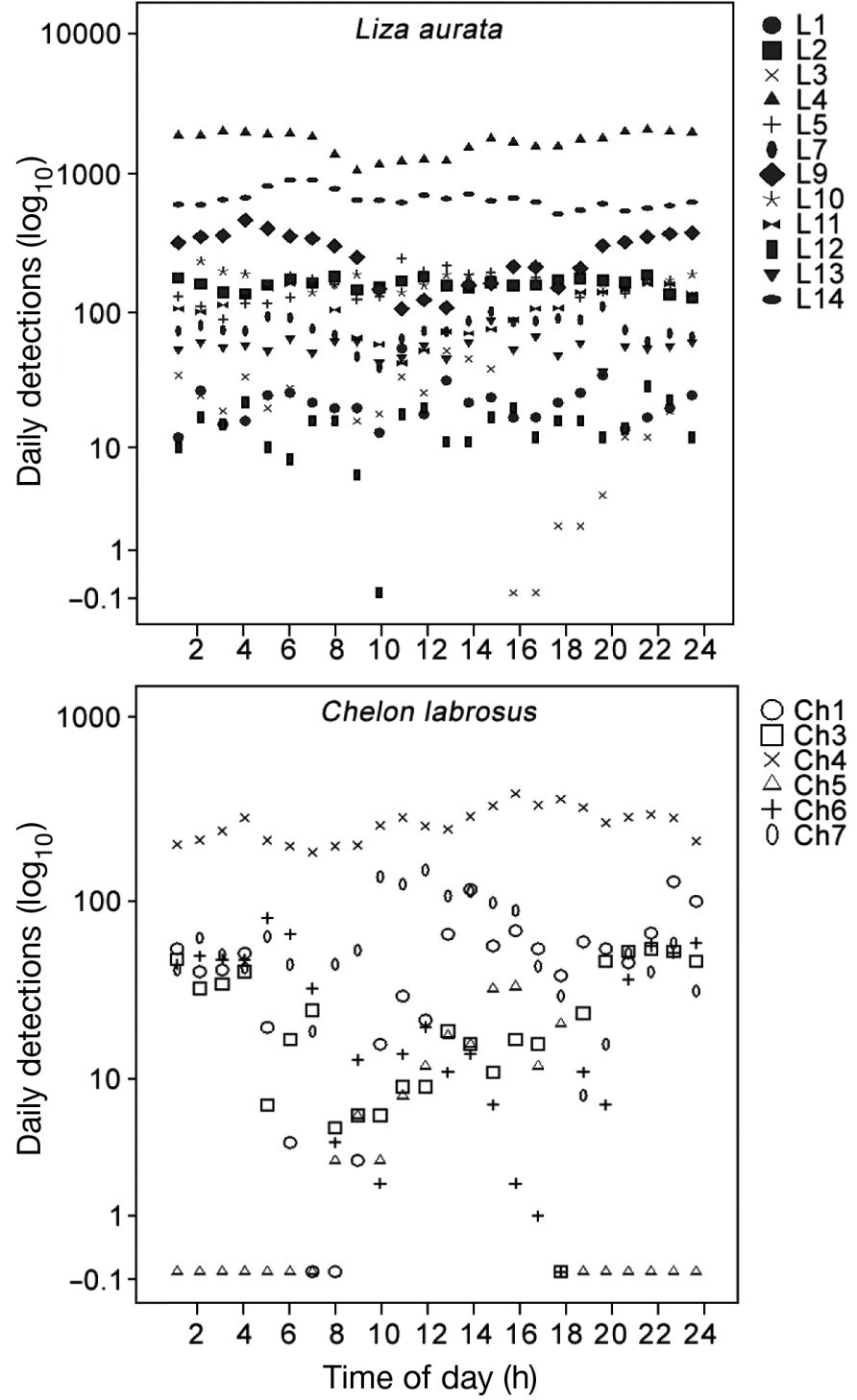

Fig. 4. Estimated marginal means of number of detections (GLM results), represented on a logarithmic scale, of each tagged individuals of Liza aurata $(\mathrm{n}=12)$ and Chelon labrosus $(\mathrm{n}=6)$ in the vicinity of fish farms throughout the day $(\mathrm{h})$

lon labrosus, but significant differences were not found (Fig. $3 ; F=1.1, \mathrm{df}=1, \mathrm{p}=0.3$ ). However, the detection rate at farms tended to vary among individual $L$. aurata (Fig. $4 ; F=4.278$, df $=11, \mathrm{p}=0.06$ ), but not among individual C. labrosus (Fig. 4; $F=3.4$, df =5, $\mathrm{p}=0.12$ ).

During daytime, the estimated marginal mean swimming depth of Liza aurata was $4.46 \pm 1.21 \mathrm{~m}$, while mean swimming depth during nighttime was $4.11 \pm$ $0.86 \mathrm{~m}$ (Fig. 5A; $F=0.3, \mathrm{df}=11, \mathrm{p}=0.6$ ). The estimated marginal mean of swimming depth of Chelon labrosus was $7.44 \pm 2.21 \mathrm{~m}$, while swimming depth during nighttime was $5.05 \pm 1.59 \mathrm{~m}$ (Fig. $5 \mathrm{~B}_{;} F=0.5$, df $=5, \mathrm{p}=$ $0.5)$. No overall differences in swimming depth were found between the 2 species $(F=1.2, \mathrm{df}=1, \mathrm{p}=0.3)$, 

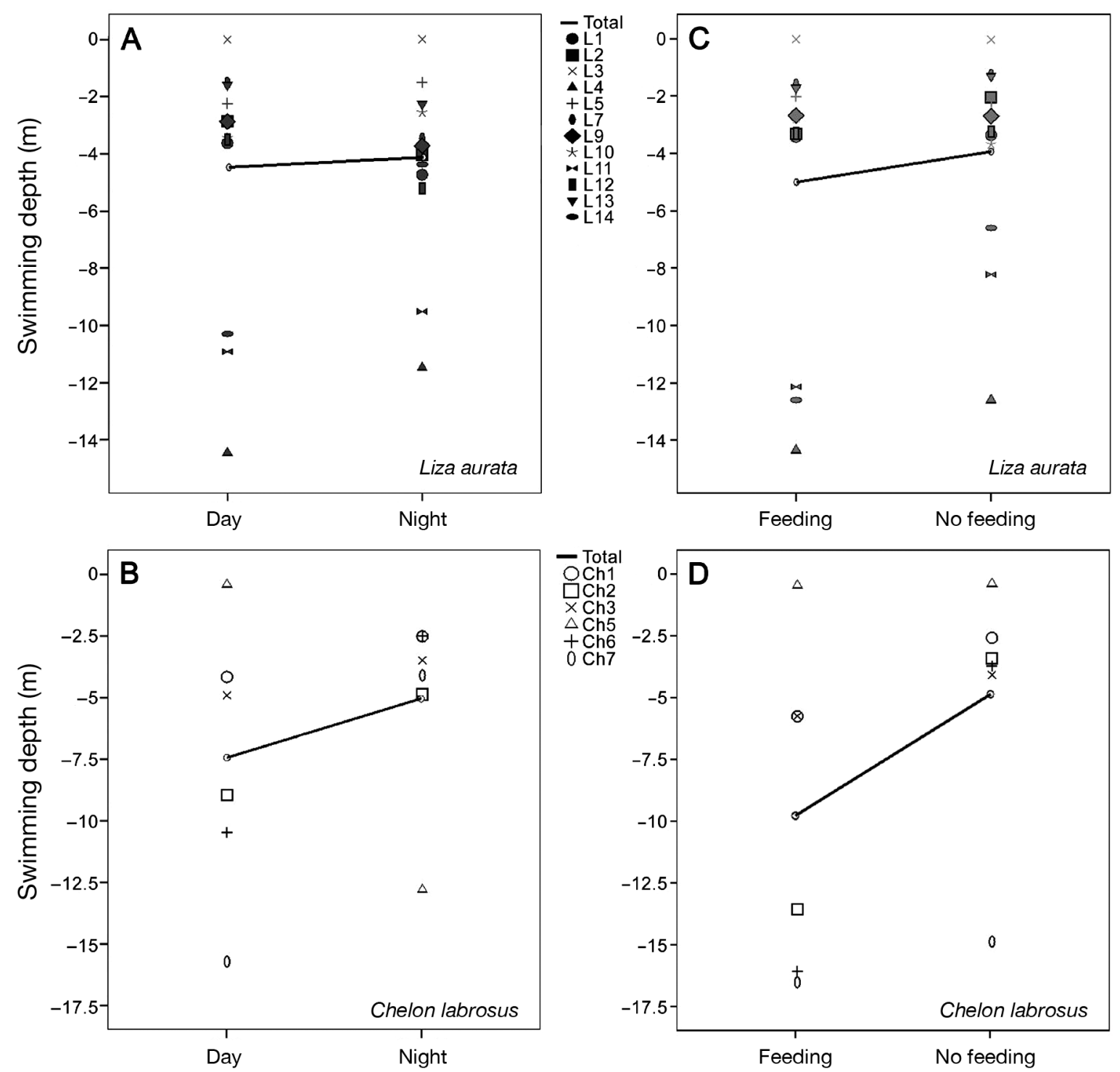

Fig. 5. Estimated marginal means of swimming depth (GLM results) at which Liza aurata $(\mathrm{n}=12)$ and Chelon labrosus ( $\mathrm{n}=6)$ were recorded in the vicinity of the farms during $(A, B)$ day- and nighttime, and $(C, D)$ periods of feeding during daytime

apart from that the swimming depth of the 2 species differed during feeding time $(F=12.8, \mathrm{p}=0.003)$. The swimming depths of $L$. aurata did not differ between feeding and non-feeding periods $(4.99 \pm 1.02 \mathrm{~m}$ vs. 3.94 $\pm 1.02 \mathrm{~m} ; F=13.6, \mathrm{df}=11, \mathrm{p}=0.09$; Fig. 5C), while the swimming depth of $C$. labrosus tended to be greater during the feeding period compared to the non-feeding period $(9.696 \pm 2.7 \mathrm{~m}$ vs. $4.85 \pm 2.08 \mathrm{~m} ; F=5.931$, $\mathrm{df}=5$, $\mathrm{p}=0.06$; Fig. 5D). Furthermore, the individual variation in swimming depth differed significantly within both species between day- and nighttime (L. aurata: $F=18.1, \mathrm{df}=11, \mathrm{p}<0.001 ;$ C. labrosus: $F=44.0, \mathrm{df}=5$, $\mathrm{p}<0.001$ ), as well as between feeding and non-feeding periods ( $L$. aurata: $F=13.6, \mathrm{df}=11, \mathrm{p}=0.004 ; C$. labrosus: $F=11.2$, df $=5, \mathrm{p}=0.02$ ).

\section{DISCUSSION}

In agreement with previous studies (Dempster et al. 2002, Smith et al. 2003, Fernandez-Jover et al. 2008), our results show that grey mullet are abundant around fish farms in the western Mediterranean Sea. In Guardamar Bay, grey mullet represented 19.4\% and $38.9 \%$ of the total wild fish number and biomass at the farms, respectively. Both Liza aurata and Chelon labrosus were frequently detected in deeper waters (around $15 \mathrm{~m}$ depth) in the vicinity of the farms, occupying the mid-water and cage substratum at the farms. This corresponds to the depths where waste feed from the cages is available. These results support results from other studies regarding attraction of wild fish to farms, 
which suggest that waste feed abundance is an important causal mechanism for attraction of wild fish to farms (Dempster et al. 2005, Tuya et al. 2006, Fernandez-Jover et al. 2008, Uglem et al. 2009). Gut content analyses have shown that waste fish feed is a major part of the diet of wild fish aggregating at fish farms (Fernandez-Jover et al. 2008). However, apart from a tendency towards detecting $C$. labrosus in deeper waters during the feeding periods, the variation in presence at farms and swimming depth of the tagged mullet was not significantly associated with time of the day or the feeding period at the farms. High variability existed among the behaviour of individual mullet; combined with the small sample size of tracked individuals, this may have masked behavioural patterns in depth distributions related to both time of day or feeding periods.

Our results also show that grey mullet attracted to fish farms may move rapidly and repeatedly both among farms and also to nearby coastal fishing areas. Similar behavioural patterns have been previously detected for other species in a completely different fish farming system (Uglem et al. 2009). Some tagged grey mullet stayed for prolonged periods around fish farms and moved frequently among several of the farms. This might indicate that some of the grey mullet, at least periodically, might exhibit a specialized behavioural pattern where they predominantly stay at or in the proximity of fish farms, most likely to forage on waste fish pellets. The proximate mechanism for attraction of wild fish to farms is unknown. However, the chemosensory system in fish is well developed (Sorensen \& Caprio 1998, Vickers 2000), and attraction to watersoluble odorants from food pellets and the large numbers of cultured fish in the cages may be one explanation (Bjørn et al. 2009). Alternatively, aquaculture activity produces significant amounts of noise (Santulli et al. 1999), which also may attract wild fish (Popper et al. 2003). Our results indicate that the presence of Liza aurata at farms tended to be higher than for Chelon labrosus, while the C. labrosus moved more often between farms and coastal areas. This is most likely a result of the varying habitat use of the 2 species, as $L$. aurata exhibit a more pelagic behaviour compared to C. labrosus, which are more euryhaline and usually frequent estuarine and coastal areas (de Sostoa et al. 1990). The finding that the swimming depths varied within the different species might be related to the fact that grey mullet usually appear in shoals of different sized individuals comprising different species, which often break up and re-form (P. Arechavala-Lopez pers. obs.). The majority of the tagged grey mullet remained within the study area for shorter periods; usually less than a week. These fish most likely moved out of the study area, but they may also have been caught by local fishermen. Nonetheless, no recaptures of tagged fish were reported in Guardamar Bay following the releases.

The findings that large numbers of mullet are attracted to fish farms, most likely to forage on waste fish feed, and that these fish can move quickly and repeatedly among farms or to local fishing areas, may have several implications for integrated coastal management of fisheries and aquaculture. Firstly, the fact that farms and fishing areas are connected through movements of wild fish supports the hypothesis that farm-attracted wild fish may be vectors of diseases or parasites between farmed and wild fish stocks (Uglem et al. 2009). This does, however, assume that farmed and wild stocks share pathogens, which in turn are transferred among these stocks. Sea bream, sea bass and several species of mugilids are similarly susceptible to infection by many different viruses (e.g. family Nodaviridae), bacteria (e.g. Listonella anguillarum, Photobacterium damselae ssp. piscicida, Chlamydia spp., Mycobacterium marinum) and parasites (e.g. Enteromyxum leei, Polysporoplasma sparis, Myxobolus spp., Ceratothoa oestroides, Caligus spp.) (Raynard et al. 2007), but whether transmission is possible between reared fish and farm-associated mugilids is unknown. Compared with other geographical regions, there are few epidemiological studies and little evidence of pathogen exchange between wild and cultured fish in the Mediterranean Sea. Further research is thus required to verify if and to what extent shared diseases are transferred between reared and wild fish stocks in this area.

The movements of the farm-associated grey mullet to adjacent fishing areas also indicate that these fish are available for the local fisheries. If fish farms act as settlement sites for wild juvenile fish, including grey mullet (Fernandez-Jover et al. 2009), and if farm activity increases wild fish biomass and fish condition (Arechavala-Lopez et al. in press), the movement of farm-associated mullet to local fishing areas might be beneficial for local fisheries. In this case, the farms might actually represent small-scale marine protected areas that 'export biomass' of exploited species (Dempster et al. 2006). However, attraction of mullet to fish farms might also make them more available for the fisheries by concentrating them in a confined area around fish farms. Indeed, increased fishing pressure around the farms has been noticed in Guardamar Bay, particularly due to the extensive use of gill nets and purse seines close to the farms (Arechavala-Lopez et al. in press). It is also possible that fish farms could disrupt the natural movement patterns and behaviour of grey mullet, and in this way affect their recruitment. Therefore, fish farms could act as artificial reefs that may increase local fish production and in turn also the 
export of biomass. However, increased aggregation of fish at farms might also lead to increased fishing effort and thus result in overexploitation of stocks by increasing access to previously unexploited stock segments and/or concentrating previously exploited segments of the stock (Grossman et al. 1997).

In conclusion, the present study supports results from earlier studies in both warm-water and cold-water ecosystems, and indicates that fish farms are connected through wild fish movements and that the spatial distribution of wild fish aggregations at farms is most likely related to specific habitat preferences or feeding requirements for different species. In addition, through the use of acoustic tagging in wild fish around fish farms, this study has demonstrated that sea-cage fish farms and local fishing grounds in the western Mediterranean Sea are connected through the movements of wild fish. Exactly how fish farms in the western Mediterranean affect wild stocks at population level is still unclear and further research is required to reveal the nature of the interaction between fish farms and wild fish stocks. In particular, research aimed at determining how farms affect the reproductive potential and spawning migrations of attracted fish, and how this, in turn, may affect the recruitment and population dynamics of wild fish stocks would be of great significance. Furthermore, our results illustrate that an integrated management of aquaculture and fisheries is imperative in order to ensure a sustainable maintenance and development of both industries according to an ecosystem approach.

Acknowledgements. We thank the staff of the Martorres, Culmar and Gramabasa fish farms for their help and their assistance in the field. We also thank the Norwegian Institute of Nature Research (NINA) for supplying the acoustic equipment. We are very grateful to E. Thorstad and F. Økland improving the manuscript and for their helpful comments. This project was partly financed by the Norwegian Research Council project ECoMA and by the FatFish project (CTM 2009-14362-C02-01), Ministerio de Ciencia e Innovación (Spanish Goverment).

\section{LITERATURE CITED}

Akyol O, Ertosluk O (2010) Fishing near sea-cage farms along the coast of the Turkish Aegean Sea. J Appl Ichthyol 26: $11-15$

Arechavala-Lopez P, Sanchez-Jerez P, Bayle-Sempere J, Fernandez-Jover D, Martinez-Rubio L, Lopez-Jimenez JA, Martinez-Lopez FJ (in press) Direct interaction between wild fish aggregations at fish farms and fisheries activity at fishing grounds: a case study with Boops boops. Aquacult Res

Bayle-Sempere JT, Valle C, Verdu A (2001) ecoCEN: a database for fish counts. FAO - AECI, Alicante (see www.ua. es/ecoCEN)

> Bjørn PA, Uglem I, Kerwath S, Sæther BS, Nilsen R (2009) Spatiotemporal distribution of Atlantic cod (Gadus morhua
L.) with intact and blocked olfactory sense during the spawning season in a Norwegian fjord with intensive salmon farming. Aquaculture 286:36-44

Blaber SJM (1997) Fish and fisheries of tropical estuaries. Chapman \& Hall, London

$>$ Carss DN (1990) Concentrations of wild and escaped fishes immediately adjacent to fish farm cages. Aquaculture 90:29-40

Coll J, Linde M, García-Rubies A, Riera F, Grau AM (2004) Spear fishing in the Balearic Islands (west central Mediterranean): species affected and catch evolution during the period 1975-2001. Fish Res 70:97-111

Coz-Rakovac R, Strunjak-Perovic I, Topic Popovic N, Hacmanjek M and others (2008) Cage culture effects on mullets (Mugilidae) liver histology and blood chemistry profile. J Fish Biol 72:2557-2569

de Sostoa A, Casals F, Fernández Colomé JV, Lobón-Cerviá J, de Sostoa FJ, Vinyoles D (1990) Peixos. In: Folch R (ed) Història Natural dels Països Catalans, Vol 11. Enciclopèdia Catalana, Barcelona, p 386-400

Dempster T, Sanchez-Jerez P, Bayle-Sempere JT, GiménezCasalduero F, Valle C (2002) Attraction of wild fish to seacage fish farms in the south-western Mediterranean Sea: spatial and short-term temporal variability. Mar Ecol Prog Ser 242:237-252

Dempster T, Fernandez-Jover D, Sanchez-Jerez P, Tuya F, Bayle-Sempere J, Boyra A, Haroun R (2005) Vertical variability of wild fish aggregations around sea-cage fish farms: implications for management. Mar Ecol Prog Ser 304:15-29

> Dempster T, Sanchez-Jerez P, Tuya F, Fernandez-Jover D, Bayle-Sempere J, Boyra A, Haroun R (2006) Coastal aquaculture and conservation can work together. Mar Ecol Prog Ser 314:309-310

Fernandez-Jover D, Lopez-Jimenez JA, Sanchez-Jerez P, Bayle-Sempere J, Gimenez-Casalduero F, MartinezLopez FJ, Dempster T (2007) Changes in body condition and fatty acid composition of wild Mediterranean horse mackerel (Trachurus mediterraneus, Steindachner, 1868) associated with sea cage fish farms. Mar Environ Res 63: $1-18$

- Fernandez-Jover D, Sanchez-Jerez P, Bayle-Sempere JT, Valle C, Dempster T (2008) Seasonal patterns and diets of wild fish assemblages associated to Mediterranean coastal fish farms. ICES J Mar Sci 65:1153-1160

Fernandez-Jover D, Sanchez-Jerez P, Bayle-Sempere JT, Arechavala-Lopez P, Martínez-Rubio L, Lopez-Jimenez JA, Martínez-Lopez FJ (2009) Coastal fish farms are settlement points for juvenile fish. Mar Environ Res 68:89-96

Forcada A, Valle C, Sanchez-Lizaso JL, Bayle-Sempere JT, Corsi F (2009) Structure and spatio-temporal dynamics of artisanal fisheries around a Mediterranean marine protected area. ICES J Mar Sci 67:191-203

Grossman GD, Jones GP, Seaman WJ (1997) Do artificial reefs increase regional fish production? A review of existing data. Fisheries 22:17-23

Harmelin-Vivien M, Harmelin J, Chauvet C, Duval C, and others (1985) Evaluation visuelle des peuplements et populations de poisons: méthodes et problèmes. Rev Ecol Terre Vie 40:467-539

Katz T, Herut B, Genin A, Angel DL (2002) Grey mullets ameliorate organically-enriched sediments below a fish farm in the oligotrophic Gulf of Aquaba (Red Sea). Mar Ecol Prog Ser 234:205-214

Kingsford M, Battershill C (1998) Studying temperate marine environments: a handbook for ecologists. Canterbury University Press, Christchurch 
Lupatsch I, Katz T, Angel DL (2003) Assessment of the removal efficiency of fish farm effluents by grey mullets: a nutritional approach. Aquacult Res 34:1367-1377

Machias A, Giannoulaki M, Somarakis S, Maravelias CD and others (2006) Fish farming effects on local fisheries landings in oligotrophic seas. Aquaculture 261:809-816

McDowall RM (1988) Diadromy in fishes. Migrations between freshwater and marine environments. Croom Helm, London

Popper AN, Fay RR, Platt C, Sand O (2003) Sound detection mechanisms and capabilities of teleost fishes. In: Collin $\mathrm{SO}$, Marshall NJ (eds) Sensory processing in aquatic environments. Springer, New York, NY, p 3-38

Porter CB, Krost P, Gordin H, Angel DL (1996) Preliminary assessment of greymullet (Mugil cephalus) as a forager of organically enriched sediments below marine fish farms. Isr J Aquacult 48:47-55

Raynard R, Wahli T, Vatsos I, Mortensen S (2007) Review of disease interactions and pathogen exchange between farmed and wild finfish and shellfish in Europe. Workpackage 1, Deliverable 1.5. Disease interactions and pathogen exchange between farmed and wild aquatic animal populations-a European network (DIPnet). VESO, Oslo

Ribeiro C, Almeida AJ, Araujo R, Biscoito M, Freitas M (2005) Fish assemblages of Cais do Carvao Bay (Madeira Island) determined by the visual census technique. J Fish Biol 67:1568-1584

Editorial responsibility: Ian Fleming, St. John's, Newfoundland, Canada
Santulli A, Modica A, Messina C, Ceffa L and others (1999) Biochemical responses of European sea bass (Dicentrarchus labrax L.) to the stress induced by off shore experimental seismic prospecting. Mar Pollut Bull 38:1105-1114

Smith C, Machias A, Giannoulaki M, Somarakis S, Papadopoulou KN, Karakassis I (2003) Diversity study of wild fish fauna aggregating around fish farm cages by means of remotely operated vehicle (ROV). In: National Center for Marine Research (NCMR) (eds) Proc 7th Hellenic Symp Oceanography and Fisheries, 6-9 May 2003, Hersonissos, Crete. NCMR, Agios Kosmas, Athens, p 227

Sorensen PW, Caprio J (1998) Chemoreception. In: Evans DH (ed) The physiology of fishes, 2nd edn. Marine Science Series. CRC Press, Boca Raton, FL, p 375-406

Tuya F, Sanchez-Jerez P, Dempster T, Boyra A, Haroun R (2006) Changes in demersal wild fish aggregations beneath a sea-cage fish farm after the cessation of farming. J Fish Biol 69:682-697

Uglem I, Dempster T, Bjørn PA, Sanchez-Jerez P, Økland F (2009) High connectivity of salmon farms revealed by aggregation, residence and repeated movements of wild fish among farms. Mar Ecol Prog Ser 384:251-260

> Verdiell-Cubedo D, Oliva-Paterna FJ, Torralba M (2006) Length-weight relationships for 22 fish species of the Mar Menor coastal lagoon (western Mediterranean Sea). J Appl Ichthyol 22:293-294

Vickers NJ (2000) Mechanisms of animal navigation in odor plumes. Biol Bull (Woods Hole) 198:203-212

Submitted: December 16, 2009; Accepted: September 13, 2010 Proofs received from author(s): October 29, 2010 